\title{
Isolation and Characterization of Zinc Tolerant Bacteria from Contaminated Sediments and Soils in Egypt
}

\author{
Eman A. El-Alkshar'; Hamed E. Abou-Aly; Taha A. Tewfike'; Rasha M. El-Meihy'; Ahmed M. Yousif ${ }^{2}$ \\ ${ }^{1}$ Agricultural Botany Department (Microbiology), Faculty of Agriculture, Benha University, \\ Moshtohor, Qalubia, 13736, Egypt. \\ ${ }^{2}$ Packaging material Department, National research center, Cairo, Egypt. \\ Corresponding author: rashaelmehy@fagr.bu.edu.eg
}

\begin{abstract}
A total of 71 zinc tolerant bacteria were, isolated from Four heavy metals contaminated sediments and soils in Egypt, three sediment samples (Upstream, midstream, downstream Al-Rahawy drain, Giza Governorate) and two agricultural soil samples (Al-Gabal Al-Asfar region and Kafr-Ilwan village, Qalubia Governorate). The minimum inhibitory concentration (MIC) and maximum tolerance concentration (MTC) under zinc $\left(\mathrm{Zn}^{+2}\right)$ concentrations ranged between 500-4500 mg/l. The most zinc tolerant isolate UR45 with MIC $4500 \mathrm{mg} / \mathrm{l}$ and MTC $4000 \mathrm{mg} / \mathrm{l}$ was identified by partial sequence of 16S rRNA genes as Alcaligenes faecalis MG257493.1 (UR45). Tolerance of $A$. faecalis to cadmium $\left(\mathrm{Cd}^{2+}\right)$, copper $\left(\mathrm{Cu}^{2+}\right)$ and lead $\left(\mathrm{Pb}^{2+}\right)$ under different concentrations $(1000-4500 \mathrm{mg} / \mathrm{l})$ was evaluated. Growth of the strain and its biosorption activities (metal uptake, metal residual, metal biosorption) at $1000 \mathrm{mg} / \mathrm{l}$ of $\mathrm{Zn}^{2+}, \mathrm{Cd}^{2+}, \mathrm{Cu}^{2+}$ and $\mathrm{Pb}^{2+}$ under different $\mathrm{pH}$ values (5-9) was studied. $\mathrm{pH} 8$ was optimum for growth in media supplemented with $\mathrm{Zn}^{2+}$ or $\mathrm{Cu}^{2+}$. Whereas, the biosorption potentials were differed according to the examined metal. Finally, enzymatic (catalase, peroxidase, polyphenol oxidase) and non-enzymatic (inhibition 2,2-DiPhenyl-2-Picrylhydrazyl hydrate (DPPH)) antioxidant activities of the A. faecalis MG257493.1 in presence of four heavy metals individually or in mixture at 1000 and $1500 \mathrm{mg} / \mathrm{l}$ were estimated. The obtained data showed that most antioxidant activities of the strain was increased with the increasing of heavy metals concentrations up to $1500 \mathrm{mg} / \mathrm{l}$.
\end{abstract}

Keywords: Heavy metals, zinc, Alcaligenes faecalis, biosorption, antioxidant activities.

\section{Introduction}

Contamination of sediments and soils with heavy metals is a major environmental problem all over the world. These inorganic pollutants are released by effluents generated from various industries (Ezzouhri et al., 2009). Even essential biological trace elements, such as $\mathrm{Zn}^{2+}$, can be toxic at high concentrations (Fang et al., 2016). Heavy metals in soils cannot be mineralized or broken down to less toxic forms (Chen et al., 2014). A large proportion of heavy metals are generally bound to organic and inorganic soil components or exist as insoluble precipitates. Therefore, developing appropriate strategies for the remediation of heavy metal contaminated soils demands urgent attention from the perspectives of environmental conservation (Aboushanab et al., 2006). In naturally polluted environments, the microbe's response to heavy metals toxicity depends on the concentration and the availability of metals and on the action of factors such as the type of metal, the nature of medium and microbial species (Ezzouhri et al., 2009).

Generally, the contaminated sites are the sources of metal resistant microorganisms (Vadkertiova and Slavikova, 2006). Similar findings of occurrence of $\mathrm{Zn}^{2+}$ metal resistant bacteria in contaminated soils, wastewater effluents, river water and sediments have been reported (Ahemad and Malik, 2012; Jackson $\boldsymbol{e t}$ al., 2012; Mgbemena et al., 2012). Additionally, microbial biomass have evolved various measures to respond to heavy metals stress via processes such as transport across the cell membrane, biosorption to cell walls, entrapment in extracellular capsules as well as precipitation and transformation of metals (Malik, 2004). Also, he proved that microorganisms isolated from contaminated sites have an excellent ability of removing significant quantities of metals both from different environments. Therefore, it is important to explore microorganisms from contaminated sources for the bioremediation of heavy metals since conventional processes such as chemical precipitation; ion exchange and reverse osmosis are uneconomical and inefficient for treating effluents of dilute metal concentrations (Gavrilesca, 2004). Heavy metal resistant bacteria have been demonstrated to exhibit high metal biosorption or bioaccumulation capacity in the laboratory setting (Bautista-Hernández et al., 2012) and some heavy metal resistant strains have been successfully applied in remediating contaminated sites elsewhere in the developed world (Ansari and Malik, 2007).

Free radicals can be generated under different stress conditions included heavy metals in the form of reactive oxygen species (ROS), such as superoxide anion radicals $\left(\mathrm{O}^{2-}\right)$, hydroxyl radicals $\left(\mathrm{OH}^{1-}\right)$, hydrogen peroxide $\left(\mathrm{H}_{2} \mathrm{O}_{2}\right)$, and singlet oxygen $\left({ }^{1} \mathrm{O}_{2}\right)$. These ROS are an entire class of highly reactive molecules derived from the normal metabolism of oxygen or from exogenous factors and agent (Chung et al. 2006). Antioxidants are compounds formed inside the cell to preserve it from oxidative damage of 
DNA, protein, lipid, and other molecules caused by ROS (Heo et al., 2006).

The aim of this study was to isolate, identify and characterize zinc tolerant bacteria from heavy metals contaminated sites in Egypt. MIC and MTC of heavy metals (zinc) for bacteria were determined and selected of the most resistant strain. Also, study the other heavy metals tolerance $\left(\mathrm{Cd}^{2+}, \mathrm{Cu}^{2+}, \mathrm{Pb}^{2+}\right)$ and the biosorption potential of the selected isolate. Moreover, study the antioxidant activities which might be useful in heavy metals bioremediation of the environment.

\section{Materials and Methods}

\subsection{Collection of samples}

Sediment samples were collected from three heavy metals contaminated sites upstream (UR), midstream (MR) and downstream (DR) of Al-Rahawy drain, Giza Governorate, Egypt and two agricultural soils irrigated with waste water were collected from AlGable Al-Asfar region (GS) and Kafr-Ilwan village (KI), Qalubia Governorate, Egypt. All samples were stored at $4^{\circ} \mathrm{C}$ until analysis.

\subsection{Heavy metals analysis}

This method is described by (Burau, 1982). The concentrations of $\mathrm{Cd}^{2+}, \mathrm{Cu}^{2+}, \mathrm{Pb}^{2+}$, and $\mathrm{Zn}^{2+}$ in the final solutions were determined with an atomic absorption spectrophotometer (Buck Model 210 VGP).

Table 1. Heavy metals concentrations in sediment and soil samples

\begin{tabular}{|c|c|c|c|c|c|c|}
\hline \multirow{2}{*}{\multicolumn{2}{|c|}{ Heavy metals }} & \multicolumn{5}{|c|}{ Samples } \\
\hline & & $\mathbf{U R}$ & MR & DR & GS & KI \\
\hline $\mathbf{C d}^{2+}$ & \multirow{4}{*}{ స్త్ } & 0.431 & 0.035 & 0.001 & 4.44 & 3.28 \\
\hline $\mathbf{C u}^{2+}$ & & 0.411 & 0.170 & 0.013 & 5.85 & 0.70 \\
\hline $\mathrm{Zn}^{2+}$ & & 0.224 & 0.195 & 0.033 & 4.63 & 3.20 \\
\hline $\mathbf{P b}^{2+}$ & & 0.070 & 0.005 & 0.004 & 0.25 & 0.15 \\
\hline \multicolumn{4}{|c|}{ UR: Upstream Al-Rahawy drain sediment } & \multicolumn{3}{|c|}{ MR: Midstream Al-Rahawy drain sediment } \\
\hline \multicolumn{4}{|c|}{ DR: Downstream Al-Rahawy drain sediment } & \multicolumn{3}{|c|}{ GS: Al-Gable, Al-Asfar } \\
\hline
\end{tabular}

\subsection{Isolation of zinc of tolerant bacteria}

The isolation of zinc tolerant bacteria was carried out on Muller-Hinton broth medium (HIMEDIA Co., Germany) supplemented with $250 \mathrm{mg} / \mathrm{Zn}^{+2}$ (1.10g/l) as $\mathrm{ZnSO}_{4} .7 \mathrm{H}_{2} \mathrm{O}$ (HIMEDIA Co., Germany) (Liu et al., 2004). $150 \mathrm{ml}$ Erlenmeyer flasks containing $90 \mathrm{ml}$ of the previous media were inoculated with $10 \mathrm{~g}$ of each sediment or soil samples and incubated at $30^{\circ} \mathrm{C} \pm 2$ for $72 \mathrm{hr}$. under shaking ( $150 \mathrm{rpm} / \mathrm{min}$.). Enriched cultures showed turbidity after 3 days of incubation were diluted up to $10^{-6}$ using sterile distilled water, then subculture onto Petri dishes containing the same solidified medium. Appearing colonies on dishes and differing in shape, color and margins were purified and maintained on the previous medium and kept at $5^{\circ} \mathrm{C}$ for further study (Moghannem et al., 2015).

\subsection{Minimum inhibitory concentration (MIC) and maximum tolerance concentration (MTC) for zinc}

MIC and MTC of zinc for 71 bacterial isolates were determined using agar plate dilution method as described by Malik and Jaiswal (2000). MullerHinton agar medium amended with different concentrations of $\mathrm{Zn}^{2+}$ namely, 500, 1000, 1500, 2000, 2500, 3000, 3500, 4000, 4500 mg/l were used. Each isolate was streaked individually on Petri dishes containing the abovementioned medium and then incubated at $30^{\circ} \mathrm{C} \pm 2$ for $72 \mathrm{hr}$. MIC is the lowest concentration that completely inhibits the visible growth of microorganisms while, the highest concentration which bacterial isolates able to grow was considered as MTC. (Banerjee et al., 2015).

\subsection{Identification of the most zinc tolerant bacterial isolate}

The highest zinc tolerant bacterial isolate was selected for identification. Total DNA extraction was carried out by CTAB method (Purohit et al., 2003). Bacteria were identified by partial sequence of $16 \mathrm{~S}$ rRNA gene following procedures reported earlier (Narde et al., 2004). A 1466bp product was amplified using $16 \mathrm{~S}$ rDNA using primers:

Forward primer:

\section{5'-AGAGTTTGATCMTGGCTCAG-3'}

Reverse primer:

\section{5'-CGGYTACCTTGTTACGACTT-3'}

Samples were identified through BLAST analysis of the partial sequences and deposited in NCBI GenBank. The sequences are deposited at GenBank for accession numbers. PCR products $(1.5 \mathrm{~kb})$ of $16 \mathrm{~S}$ rRNA genes were used for DNA sequencing. Sequences of related bacteria with greatest similarity to the $16 \mathrm{~S}$ rRNA sequence of the Selected bacterial isolate were extracted from nucleotide sequence databases and aligned using CLUSTAL W (1.81) Multiple Sequence. A phylogenetic tree was constructed using the neighbor-joining distance method with the MEGA4 software (Tamura et al., 
2007) and the reliability of the bootstrap consensus inferred from 1000 replicates. The $16 \mathrm{~S}$ rRNA gene sequences of the bacterial isolate reported in this paper were deposited in the DDBJ/EMBL/GenBank nucleotide sequence databases with the Accession numbers: UR45: BankIt2056333 Alcaligenes MG257493.1

\subsection{Tolerance of the potent strain for $\mathrm{Cd}^{2+}, \mathrm{Cu}^{2+}$} and $\mathbf{P b}^{2+}$

The most zinc tolerant strain was grown on Muller-Hinton agar medium containing different concentrations of three heavy metals (HIMEDIA Co., Germany) in addition to zinc as follow: cadmium at 1000, 1500, $2000 \mathrm{mg} / \mathrm{l}$ as $\mathrm{CdCl}_{2}$; lead at 1000, 2000, $3000 \mathrm{mg} / \mathrm{l}$ as $\mathrm{Pb}\left(\mathrm{CH}_{3} \mathrm{COO}\right)_{2}$, copper at 1000,1500 , $2000 \mathrm{mg} / \mathrm{l}$ as $\mathrm{CuSO}_{4}$ and zinc at 2000, 3000, $4000 \mathrm{mg} / \mathrm{l}$ as $\mathrm{ZnSO}_{4}$; to find out the most zinc tolerant against the above mentioned metals (Congeevaram et al., 2007).

2.6. Effect of pH on growth and heavy metals biosorption potential for the most zinc tolerant isolate

The most zinc tolerant isolate was grown in Muller-Hinton broth medium individually supplemented with four heavy metals $\mathrm{Zn}^{2+}, \mathrm{Cd}^{2+}, \mathrm{Pb}^{2+}$ and $\mathrm{Cu}^{2+}$ at $1000 \mathrm{mg} / \mathrm{l}$ and adjusted to different $\mathrm{pH}$ values $(5.0,6.0,7.0,8.0$ and 9.0) and was kept constant during the experiment by the addition of $0.1 \mathrm{~N}$ $\mathrm{HCl}$ or $1 N \mathrm{NaOH}$ as required. The tubes were incubated at $30^{\circ} \mathrm{C} \pm 2$ for $72 \mathrm{hr}$. under shaking (150 $\mathrm{rpm} / \mathrm{min}$.). The optical density of bacterial growth measured at $600 \mathrm{~nm}\left(\mathrm{OD}_{600}\right)$ using spectrophotometer (Sco. Tech, SP UV-19) (Stevenson et al., 2016). Then, the bacterial culture was centrifuged at $5000 \mathrm{xg}$ for $20 \mathrm{~min}$. Then, the following parameters were estimated:

- Bacterial dry weight was determined by harvesting the cells by centrifugation at 5,000 xg for $20 \mathrm{~min}$. Harvested cells were washed twice with distilled water and desiccated in an oven at $80^{\circ} \mathrm{C}$ for $48 \mathrm{hr}$.

- The residual ion concentration of metal was detected in the supernatants using the atomic absorption spectrophotometer (Buck Model 210 VGP).

- The amounts of metal uptake (mg/l) was calculated according to the equation by Shetty and Rajkumar (2009):

Heavy metal uptake (mg/l)

$$
=\frac{\mathrm{V}(\mathrm{CI}-\mathrm{CF})}{\text { dry biomass weight }(\mathrm{g})}
$$

Where:

$\mathrm{V}$ : volume of reaction $\quad \mathrm{CI}$ : Initial metal
concentration $\quad \mathrm{CF}$ : Final metal concentration
(Residual)

- Heavy metal biosorption (\%) was calculated according to the equation by Shetty and Rajkumar (2009):

Efficiency of biosorption $(\%)=\frac{(\mathrm{CI}-\mathrm{CF})}{\mathrm{CI}} \times 100$

\subsection{Estimation of antioxidant activities}

\subsubsection{Preparation of cell free extract (CFE)}

Tubes of Muller-Hinton broth medium ( $\mathrm{pH}$ $7.5 \pm 0.2$ ) individually amended with four heavy metals $\left(\mathrm{Zn}^{2+}, \mathrm{Cd}^{2+}, \mathrm{Pb}^{2+}\right.$ and $\left.\mathrm{Cu}^{2+}\right)$ at 1000 and $1500 \mathrm{mg} / \mathrm{l}$ and in mixtures from them, then inoculated with $1 \%$ of the overnight grown zinc tolerant isolate culture and incubated at $30^{\circ} \mathrm{C} \pm 2$ for $18 \mathrm{hr}$. using shaking incubator $(150 \mathrm{rpm} / \mathrm{min})$. CFE was obtained by centrifugation at $10,000 \times \mathrm{xg}$ for $5 \mathrm{~min}$ at $4^{\circ} \mathrm{C}$ and kept at $4^{\circ} \mathrm{C}$ for enzymatic and non-enzymatic antioxidant assays.

\subsubsection{Non-enzymatic antioxidant assay}

DPPH free radical scavenging assay was measured as non-enzymatic assay using the procedure described by Heo et al. (2005) as follows: $500 \mu \mathrm{L}$ of CFE, 3000 $\mu \mathrm{L}$ of a freshly prepared solution of 2,2-DiPhenyl-2Picryl hydrazyl hydrate (DPPH) at a concentration of $5 \mathrm{mg} / 100 \mathrm{ml}$ ethanol was added. Control was prepared using $500 \mu 1$ of ethanol addition to $3000 \mu \mathrm{L} \mathrm{DPPH}$ solution, mixed and incubated for $30 \mathrm{~min}$ in dark. Absorbance (As) was measured at $517 \mathrm{~nm}$ after 30 min. The percentage of radical scavenging activity was calculated according to the following equation:

$\%$ Residual of DPPH after $30 \mathrm{~min}$

$$
=\frac{\text { As517 control }- \text { As517 sample }}{\text { As517 control }} \times 10
$$

\% Inhibited of DPPH after $30 \mathrm{~min}$

$$
=\% \text { Residual of DPPH }-100
$$

\subsubsection{Enzymatic antioxidant assay}

Three oxidative enzymes (catalase, peroxidase and polyphenol oxidase) were determined spectrophotometrically as follows:

- Catalase activity (CAT) (EC 1.11.1.6) was determined by monitoring the decrease in absorbance at $240 \mathrm{~nm}$ resulting from the decomposition of $\mathrm{H}_{2} \mathrm{O}_{2}$. A complete reaction mixture was including $1500 \mu \mathrm{L}$ of $100 \mathrm{~m} M$ potassium phosphate buffer ( $\mathrm{pH} 7.0$ ), 500 $\mu \mathrm{L}$ of $75 \mathrm{mM} \mathrm{H} \mathrm{O}_{2}, 200 \mu \mathrm{L}$ of enzyme extract and 800 $\mu \mathrm{L}$ of double distilled water (DDW), in quarts cuvettes as described by Aebi (1984). One unit of enzyme activity was defined as absorbance per min.

- $\quad$ Peroxidase activity (POD) (EC 1.11.1.9) was determined using 4-methylcatechol as substrate. The increase in the absorption caused by oxidation of 4-methylcatechol by $\mathrm{H}_{2} \mathrm{O}_{2}$, was measured at $420 \mathrm{~nm}$. The reaction mixture contained $100 \mu \mathrm{L}$ of $100 \mathrm{mM}$ potassium phosphate buffer ( $\mathrm{pH} 7.0), 500 \mu \mathrm{L}$ of $5 \mathrm{mM}$

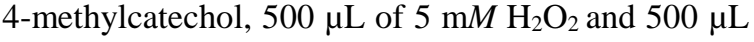
of crude extract in a total volume of $4000 \mu \mathrm{L}$ by DDW at room temperature. One unit of enzyme activity was defined as 0.001 change in absorbance per min, under assay conditions (Onsa et al., 2004).

- Polyphenol oxidase activity (PPO) (EC 1.10.3.1) was carried out by measuring the increase in absorbance at $420 \mathrm{~nm}$ for 4-methylcatechol. The assay was performed with $100 \mu \mathrm{L}$ of $100 \mathrm{~m} M$ sodium phosphate buffer ( $\mathrm{pH} 7.0$ ), $500 \mu \mathrm{L}$ of $5 \mathrm{mM}$ 4methylcatechol and $500 \mu \mathrm{L}$ of crude extract at room 
temperature. Total volume of reaction mixture was $3000 \mu \mathrm{L}$ with DDW. One unit (U) of enzyme activity was defined as the amount of the enzyme that caused a change of 0.001 in absorbance per min (Oktay et al., 1995).

\section{Results and Discussion}

\subsection{Isolation of zinc tolerant bacteria}

A total of 5 samples ( 3 sediments and 2 soils) were collected from heavy metals contaminated sites in Egypt. A total of 71 zinc tolerant bacterial isolates were recovered on Muller-Hinton agar supplemented with $250 \mathrm{mg} / \mathrm{l}$ concentration of zinc sulphate heptahydrate by pouring plate method (Fig. 1). These results were in accordance with Sen and Joshi (2016) who collected 12 soil samples from contaminated sites and isolated 23 indigenous bacterial strains on nutrient agar medium supplemented with $1000 \mathrm{mg} / \mathrm{l}$ concentration of $\mathrm{ZnSO}_{4} .7 \mathrm{H}_{2} \mathrm{O}$.

Thirteen isolates were isolated from Upstream AlRahawy drain sediment (UR33-UR45), nineteen isolates were isolated from Midstream Al-Rahawy drain sediment (MR108-MR127), ten isolates were isolated from Downstream Al-Rahawy drain sediment (DR213-DR222), fourteen isolates were isolated from Al-Gabal Al-Asfar region soil (GS286-GS299) and fifteen isolates were isolated from Kafr-Ilwan village soil (KE356-KE370). Also, data showed that the highest and the lowest numbers of isolates were obtained from Midstream and Downstream AlRahawy drain sediments, respectively.

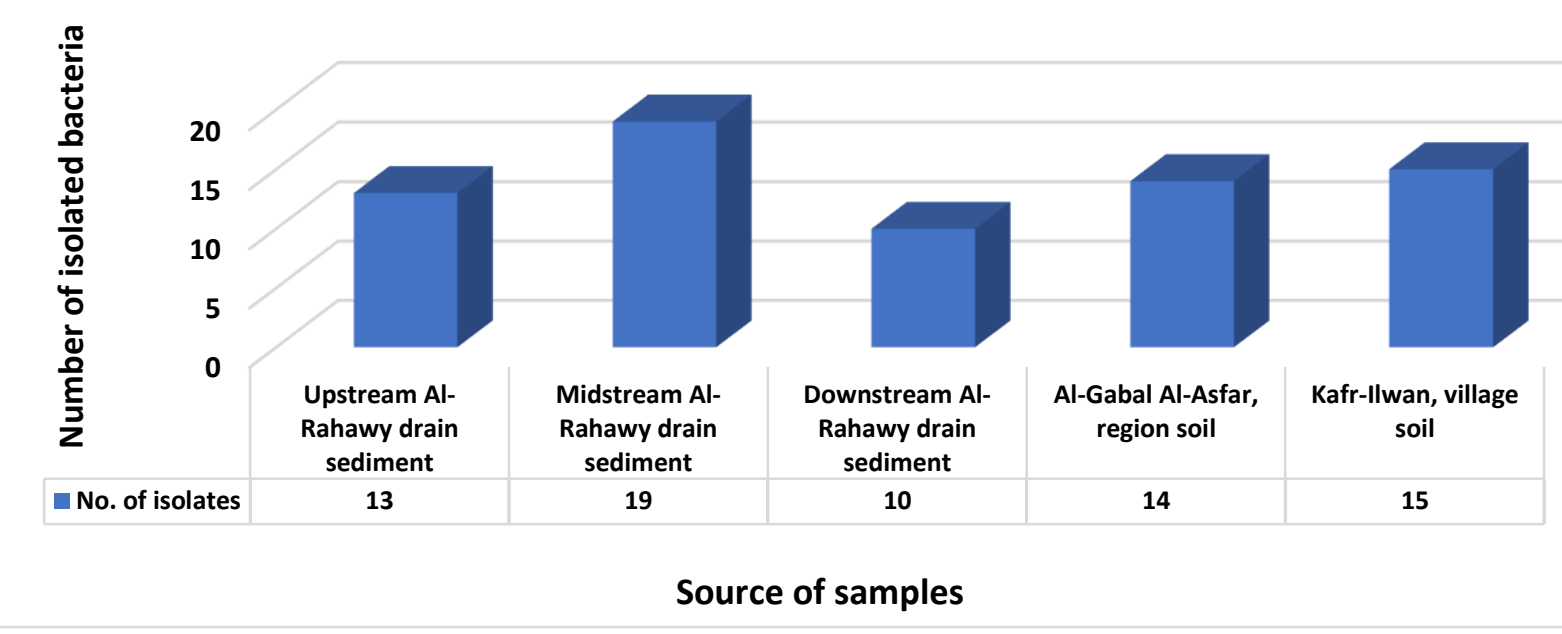

Fig. 1. Number of isolated bacteria from five contaminated sites under $250 \mathrm{mg} / \mathrm{l}$ of zinc.

\subsection{Minimum inhibitory concentration (MIC) and maximum tolerance concentration (MTC) for zinc}

All the 71 bacterial isolates were subjected to Muller-Hinton supplemented with different concentrations $(500,1000,1500,2000,2500,3000$, 3500,4000 and $4500 \mathrm{mg} / \mathrm{l}$ ) of $\mathrm{Zn}^{2+}$ for determination of MIC and MTC (Fig2). The MIC values for all isolates ranged between $1000 \mathrm{mg} / \mathrm{l}$ to $4500 \mathrm{mg} / \mathrm{l}$. Among these isolates, only three isolates namely, GS 296, KE364 and KE365 showed low MIC values 1000 $\mathrm{mg} / \mathrm{l}$. Moreover, $14.88 \%$ of isolates have MIC value at $1500 \mathrm{mg} / \mathrm{l} ; 6.2 \%$ of isolates have MIC value at 2000 $\mathrm{mg} / \mathrm{l} ; 2.48 \%$ of isolates have MIC value $2500 \mathrm{mg} / \mathrm{l}$; $21.08 \%$ of isolates have MIC value at $3000 \mathrm{mg} / \mathrm{l}$; $18.6 \%$ isolates have MIC value at $3500 \mathrm{mg} / \mathrm{l} ; 19.84 \%$ of isolates have MIC value at $4000 \mathrm{mg} / \mathrm{l}$ while, $1.24 \%$ (only one isolate, UR45) has MIC value at $4500 \mathrm{mg} / \mathrm{l}$. These results were in harmony with Sen and Joshi (2016) who demonstrated that the MIC values for 23 zinc resistant isolates ranged between $2000 \mathrm{mg} / \mathrm{l}$ to
$3100 \mathrm{mg} / \mathrm{l}$. Respecting the MTC values, all tested isolates have MTC values of zinc ranged between 500 $\mathrm{mg} / \mathrm{l}$ to $4000 \mathrm{mg} / \mathrm{l}$. The highest MTC value was observed with the isolate UR45 which isolated from Upstream Al-Rahawy drain, Giza Governorate at $4000 \mathrm{mg} / \mathrm{l}$ zinc sulphate heptahydrate. Therefore, the isolate UR45 was selected for further identification on the basis of $16 \mathrm{~S}$ rRNA and characterization.

Owolabi and Hekeu (2015) estimated the MTC for $\mathrm{Zn}^{2+}$ by zinc-resistant bacteria, they found that MTC value was ranged between 300 and $2000 \mathrm{mg} / \mathrm{l}$, depending on the bacterial strains. Also, they reported that the method for MTC examination of heavy metals for resistant bacteria have been inconsistent from study to study; while some have used liquid media (Hassen et al., 1998), most have conducted the determinations in solid media (Xu et al., 2014) as was done in the present study. It is generally considered that heavy metals are more toxic in liquid than in solid media due to more dispersion in the culture (Haferburg et al., 2007). 


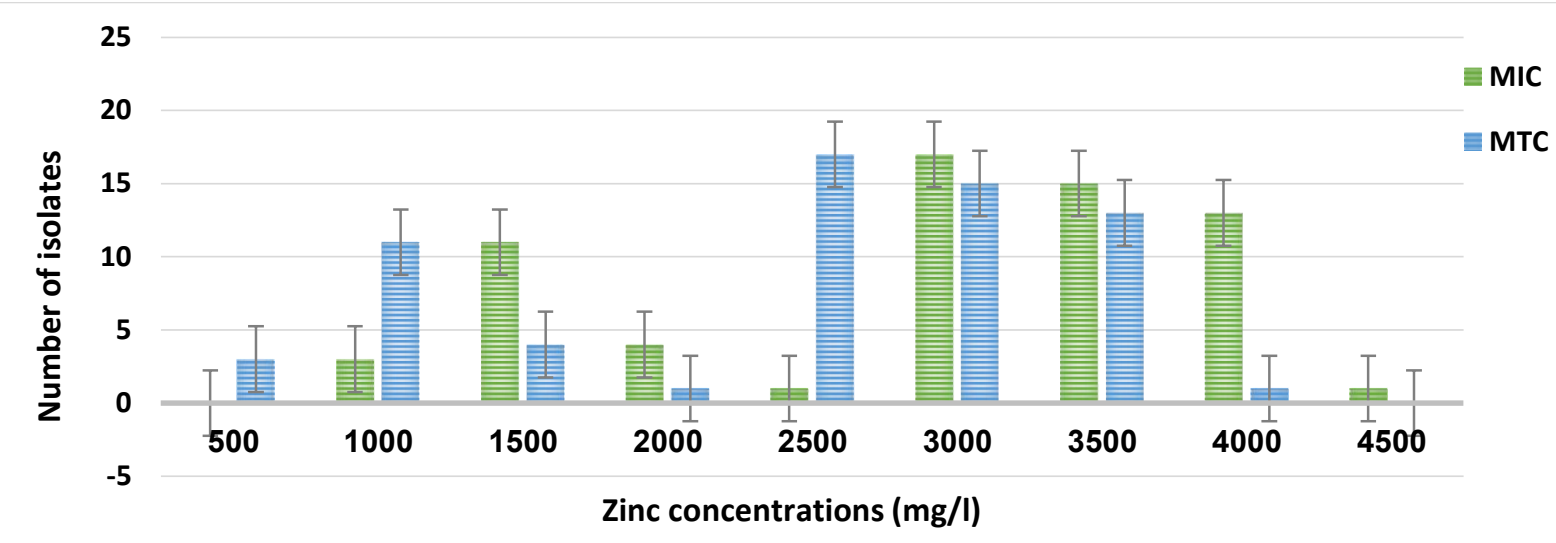

Fig. 2. Minimum inhibitory concentration (MIC) and maximum tolerance concentration (MTC) tolerance of zinc on bacterial isolates from different contaminated sites.

\subsection{Identification of the most zinc tolerant isolate UR45}

Amplification of $16 \mathrm{~S}$ rRNA of the most zinc tolerant isolate UR45 and its sequencing were carried out and BLAST analysis of the complete sequences of $16 \mathrm{~S}$ rRNA revealed the isolate to be Alcaligenes faecalis (GenBank accession nos.: MG257493.1). Distribution of the various strains on the phylogenetic tree showed that the isolate was closely related to the reference standard strains. The phylogenetic tree (Fig. 3) showed that the identified bacterium was
Alcaligenes faecalis MG257493.1 which classified as: phylum: Proteobacteria, class: Betaproteobacteria, order: Burkholderiales, family: Alcaligenaceae. Similar trend of results was observed by Sen and Joshi (2016) who reported that proteobacteria were identified as the dominant group of bacteria with tolerance to heavy metals. Also, Ansari et al. (2016) isolated six bacterial isolates from contaminated soil and characterized based on 16SrRNA gene sequences four of them are Alcaligenes spp.

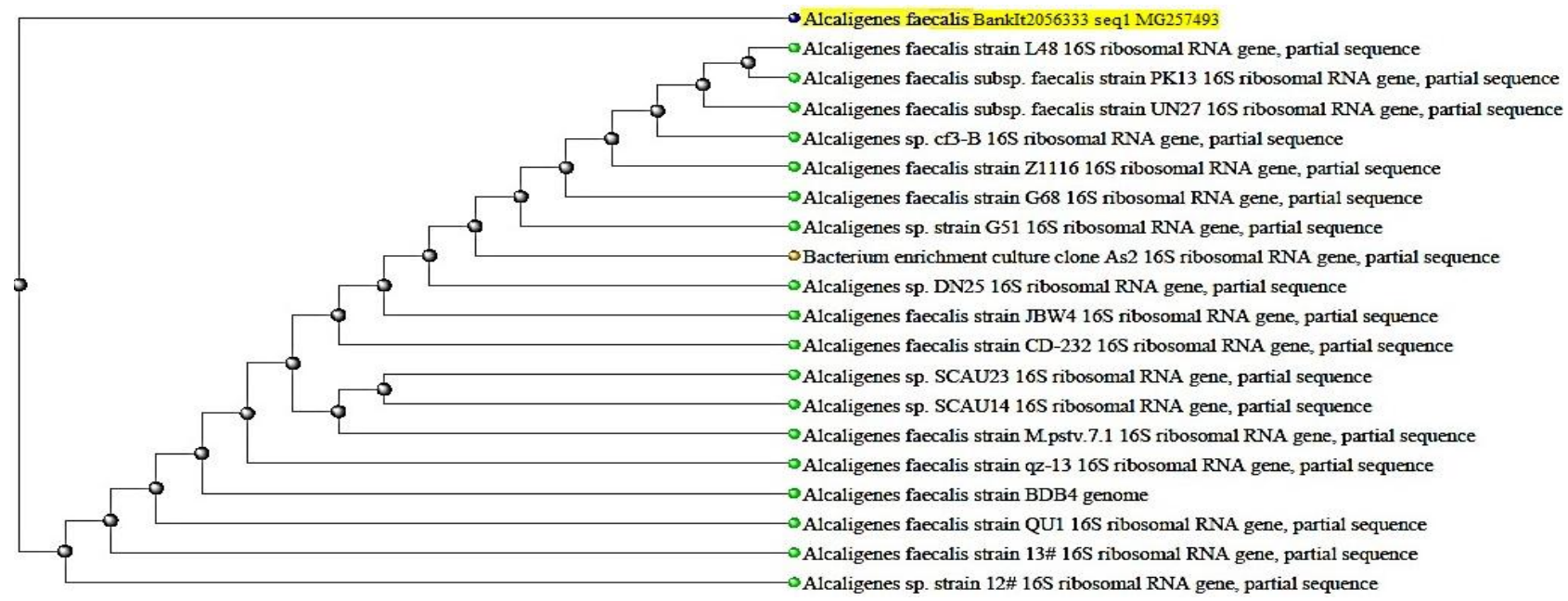

Fig.3. Phylogenetic tree showing interrelationships of the zinc tolerant isolate based on 16SrRNA sequences.

\subsection{Tolerance of zinc tolerant Alcaligenes faecalis MG257493.1 to different heavy metals}

Obtained results from the MIC analyses revealed that Al. faecalis MG257493.1 was the most tolerant bacteria to $\mathrm{Zn}^{2+}$. For this reason, it was tested for tolerance against different heavy metals $\mathrm{Cd}^{2+}, \mathrm{Pb}^{2+}$ and $\mathrm{Cu}^{2+}$ at different concentrations ranged from 1000 $\mathrm{mg} / \mathrm{l}$ to $4500 \mathrm{mg} / \mathrm{l}$. The degree of tolerance was measured by minimum inhibitory concentration (MIC) and maximum tolerance concentration (MTC) in the presence of each metal. In this respect, data graphically illustrated by Fig (4) clearly indicated that Al. faecalis MG257493.1 was more sensitive to copper than other metals with MIC value $(2000 \mathrm{mg} / \mathrm{l})$ followed by cadmium with MIC value $(2500 \mathrm{mg} / \mathrm{l})$. Moreover, MIC of $\mathrm{Zn}$ and $\mathrm{Pb}$ against Al. faecalis MG257493.1 was $4500 \mathrm{mg} / \mathrm{l}$ and $3500 \mathrm{mg} / \mathrm{l}$, respectively. This high incidence and multiple nature of metal resistance might be the result of continuous exposure of these isolates to more than one heavy 
metal. Additionally, MTC values for the $\mathrm{Cd}, \mathrm{Zn}, \mathrm{Pb}$ and $\mathrm{Cu}$ were $2000 \mathrm{mg} / \mathrm{l}, 4000 \mathrm{mg} / \mathrm{l}, 3000 \mathrm{mg} / \mathrm{l}$ and $1500 \mathrm{mg} / \mathrm{l}$, respectively.

These metal-resistant bacteria can play important role in the cleanup of contaminated environment because resistance to the metals is a general approach that occurs in the biological management of contaminated surroundings (Filali et al., 2006). Based on the ability of identified strain to resist four heavy metals (Fig 4), Al. faecalis MG257493.1 was further tested for their potential used in biosorption. Biosorption of heavy metals by microorganisms has received rapid attention in recent times to clean up the contaminated surroundings (Farhadian et al., 2008).
Moreover, Owolabi and Hekeu (2015) reported that some of the $\mathrm{Zn}^{2+}$ resistant bacterial isolates showed resistance to $\mathrm{Pb}^{2+}$. Also, in results by Ahemad and Malik (2012)who found that zinc resistant bacteria belonging to genus Pseudomonas sp. exhibited coresistance against $\mathrm{Cu}^{2+}, \mathrm{Hg}^{2+}, \mathrm{Cd}^{2+}, \mathrm{Ni}^{2+}, \mathrm{Pb}^{2+}, \mathrm{Cr}^{3+}$ and $\mathrm{Cr}^{6+}$ in addition to $\mathrm{Zn}^{2+}$. Additionally, efflux transporters play an important role in heavy metal homeostasis of different heavy metals such as $\mathrm{Zn}^{2+}$, $\mathrm{Cu}^{2+}, \mathrm{Pb}^{2+}, \mathrm{Cd}^{2+}$ and $\mathrm{Ag}^{2+}$ (Owolabi and Hekeu, 2015). An alternative resistance mechanism of $\mathrm{Zn}^{2+}$ and $\mathrm{Pb}^{2+}$ dependent upon metabolic energy of microorganisms is the bioaccumulation of both heavy metals (Augusto da Costa and Duta, 2001).

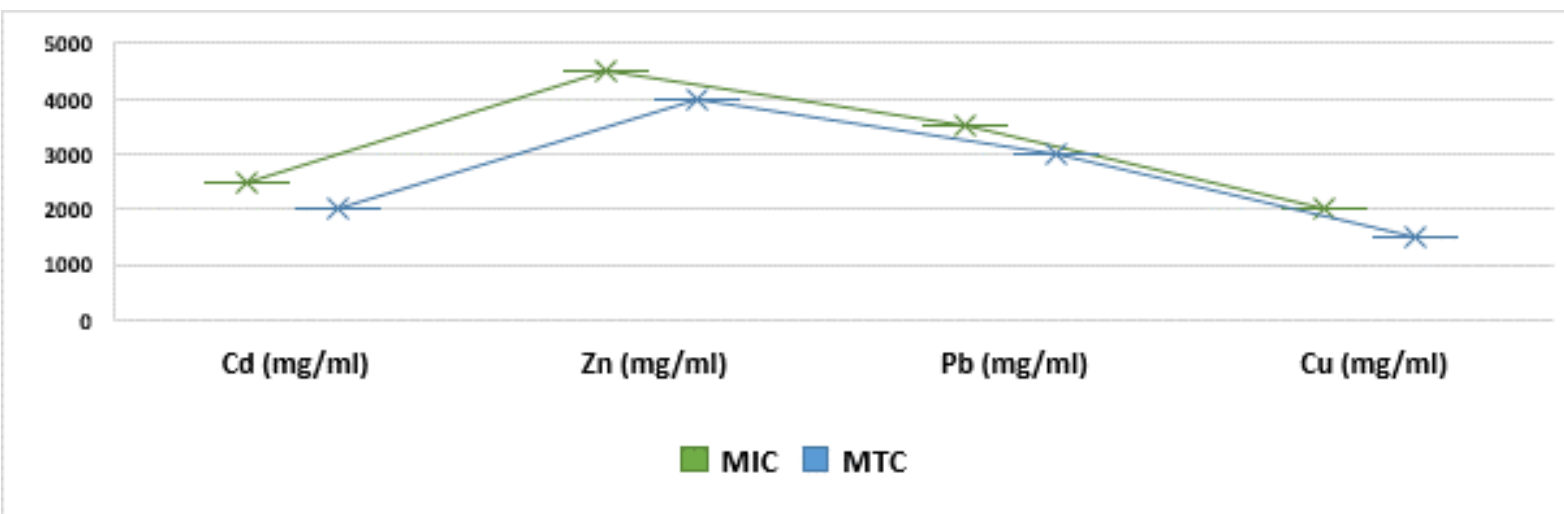

Fig.4. The MIC and MTC values for A. faecalis MG257493.1 under different concentrations of heavy metals.

\subsection{Effect of $\mathrm{pH}$ on biosorption potential by $\mathrm{Al}$. faecalis in presence of different heavy metals}

In this experiment, the identified strain Al. faecalis MG257493.1 was examined under different $\mathrm{pH}$ values in media supplemented with four heavy metals $\left(\mathrm{Cd}^{2+}\right.$, $\left.\mathrm{Cu}^{2+}, \mathrm{Zn}^{2+}, \mathrm{Pb}^{2+}\right)$ at $1000 \mathrm{mg} / \mathrm{l}$. In this respect, $\mathrm{pH}$ effects on Al. Faecalis MG257493.1, data presented in Table (2) indicated that the efficiency of biosorption and metal uptake were higher at $\mathrm{pH} 7$ than other $\mathrm{pH}$ values. This trend of results was true under four examined heavy metals. Moreover, the optimum $\mathrm{pH}$ value for biomass dry weight was varied according to the heavy metal presence in media. Data indicated that the highest biomass dry weight was recorded at $\mathrm{pH} 6$ and 8 in media supplemented with $\mathrm{Cu}^{2+}$ and $\mathrm{Pb}^{2+}$, respectively.

Whereas, $\mathrm{pH} 9$ was the optimum for biomass dry weight in media supplemented with $\mathrm{Cd}^{2+}$ or $\mathrm{Zn}^{2+}$.

Additionally, data recorded in Table (2) also showed that the optimum $\mathrm{pH}$ values which gave higher $\mathrm{Cd}^{2+}$ and $\mathrm{Pb}^{2+}$ concentrations in biomass were 6 and 9 , respectively. While, $\mathrm{pH} 8$ was the optimum value for highest $\mathrm{Cu}^{2+}$ and $\mathrm{Zn}^{2+}$ concentrations in biomass.

Generally, $\mathrm{Cd}^{2+}$ was absorbed higher than other heavy metals by Al. Faecalis MG257493.1 at $\mathrm{pH} 6$ and 7. Also, the biosorption efficiency was increased with the increasing of $\mathrm{pH}$ value and reach at maximum at $\mathrm{pH} 7$ then decreased with the increasing of $\mathrm{PH}$ value. This trend of results was observed in metal uptake by the same bacterial strain. These results are in agreement with those obtained by Green-Ruiz $\boldsymbol{e t}$ al. (2008) who reported that the maximum value of $\mathrm{Zn}$ (II) ions uptake occurred at $\mathrm{pH} 6$ and 7 by Bacillus circulans (D21) reaching to 25.40 and $25.97 \%$ of the initial metal concentration, respectively, however the lowest biosorption value was observed at $\mathrm{pH} 5$ which showed 11.86\%. Mohamed and Abo-Amer (2012) observed similar results using as bioremediation agents, accumulating metal well in comparison to HM-6 i.e Bacillus cereus. HM-7 i.e Alcaligenes sp showed highest percentage of metal accumulation i.e $38.24 \%$ biosorption and only $37.48 \%$ was left in supernatant, as well as Ting and Choong (2009) in their comparison between the ability of a Trichoderma isolate to bioaccumulate and bio-absorb.

These results revealed that utilization of the metalresistant bacteria for biosorption is a successful approach for the removal of heavy metals (Filali et al., 2006). Microorganisms able to achieve different transformation and immobilization processes, one of them is bioaccumulation, based on the incorporation of metals inside the biomass and another process is biosorption, in which metallic ions remain at the cellular surface by different mechanisms 
(Vijayaraghavan and Yun, 2008). The effects of metals on the growth of Alcaligenes spp. were investigated by determining the $\mathrm{OD}_{600}$. The growth of the strains was responses towards media supplemented with metals at $4000 \mathrm{mg} / \mathrm{l}$. The highest percent of accumulation viz. biosorption (in cell wall) and bioaccumulation (in intercellular space) was observed in Alcaligenes sp. heavy metal resistant strain in supernatant (Ansari et al., 2016). According .Also, Issazadeh et al. (2013) reported that microbial exposure to heavy metals selects and maintains microbial variants able to tolerate the harmful effects of metals. Various and efficient metal resistance mechanisms have been identified in diverse species of bacteria. Moreover, Augusto da Costa and Duta (2001) reported that the maximum zinc bioaccumulations were $4.3 \mathrm{~mol} / \mathrm{g}$ biomass for $B$. sphaericus, $4.6 \mathrm{~mol} / \mathrm{g}$ biomass for $B$. cereus, $4.8 \mathrm{~mol} / \mathrm{g}$ biomass for Bacillus sp. and $5.0 \mathrm{~mol} / \mathrm{g}$ biomass for $B$. subtilis.

Table 2. Effect of $\mathrm{pH}$ on bacterial growth and biosorption potentials under different heavy metals by Al. faecalis MG257493.1.

\begin{tabular}{|c|c|c|c|c|c|c|}
\hline $\begin{array}{l}\text { Heavy } \\
\text { metals }\end{array}$ & PH & $\begin{array}{c}\text { Residual } \\
\text { metals cons. } \\
\text { mg/l }\end{array}$ & $\begin{array}{c}\text { Efficiency of } \\
\text { biosorption } \\
(\%)\end{array}$ & $\begin{array}{c}\text { Biomass dry } \\
\text { weight } \\
\text { (mg/g) }\end{array}$ & $\begin{array}{l}\text { Metals uptake } \\
\text { (mg/g dry } \\
\text { weight) }\end{array}$ & $\begin{array}{c}\text { Metals cons. } \\
\text { in biomass } \\
\mathrm{mg} / \mathrm{g}\end{array}$ \\
\hline \multirow{5}{*}{$\mathrm{Cu}$} & 5 & 420 & $\bullet \wedge .0$ & 0.102 & 51.32 & 150.5 \\
\hline & 6 & 340 & 77.0 & 0.113 & 52.58 & 280.4 \\
\hline & 7 & 210 & V9.0 & 0.099 & 71.81 & 290.9 \\
\hline & 8 & 362 & $7 r .0$ & 0.10 & 56.70 & 483.5 \\
\hline & 9 & 550 & \&0.0 & 0.101 & 40.10 & 360.6 \\
\hline \multirow{5}{*}{ Cd } & 5 & 410 & 09.0 & 0.122 & 43.54 & 100.0 \\
\hline & 6 & 169 & 83.1 & 0.100 & 74.79 & 379.4 \\
\hline & 7 & 151 & 84.9 & 0.100 & 76.41 & 300.1 \\
\hline & 8 & 390 & 61.0 & 0.114 & 48.18 & 189.3 \\
\hline & 9 & 450 & 55.0 & 0.125 & 36.62 & 130.6 \\
\hline \multirow{5}{*}{ Zn } & 5 & 530 & 47.0 & $\begin{array}{l}0.122 \\
\end{array}$ & 34.68 & 160.3 \\
\hline & 6 & 366 & $\begin{array}{l}63.4 \\
\end{array}$ & 0.100 & 57.06 & 200.0 \\
\hline & 7 & 300 & 70.0 & 0.100 & 63.00 & 190.7 \\
\hline & 8 & 520 & $\begin{array}{l}48.0 \\
\end{array}$ & 0.105 & 41.16 & 465.6 \\
\hline & 9 & 569 & 43.1 & 0.112 & 34.64 & 380.5 \\
\hline \multirow{5}{*}{$\mathbf{P b}$} & 5 & 370 & $\begin{array}{l}63.0 \\
\end{array}$ & 0.103 & 55.06 & 200.0 \\
\hline & 6 & 350 & 65.0 & 0.103 & 56.81 & 90.36 \\
\hline & 7 & 200 & 80.0 & $\begin{array}{l}.100 \\
\end{array}$ & 72.00 & 179.3 \\
\hline & 8 & 422 & $\begin{array}{l}57.8 \\
\end{array}$ & 0.113 & 46.05 & 150.0 \\
\hline & 9 & 400 & 60.0 & 0.100 & 54.0 & 290.9 \\
\hline
\end{tabular}

\subsection{Estimation of antioxidant activities}

In this experiment, the antioxidant activities of $A l$. faecalis MG257493.1 filtrate under different heavy metals individually or in mixture were estimated at two concentrations (1000 and $1500 \mathrm{mg} / \mathrm{l}$ ). Regarding this trend, data in Table (3) clearly indicated that the highest residual of DPPH in Al. faecalis MG257493.1 filtrate was observed in filtrate without any heavy metals followed by filtrate contained the mixture of heavy metals at $1500 \mathrm{mg} / \mathrm{l}$. Moreover, it was clear that the inhibition of DPPH was higher in filtrate amended with all heavy metals either individually or in mixture at $1500 \mathrm{mg} / \mathrm{l}$ than $1000 \mathrm{mg} / \mathrm{l}$.

The highest inhibition of DPPH was recorded in media supplemented with copper at $1500 \mathrm{mg} / \mathrm{l}$ followed by cadmium at the same concentration. Although this strain was isolated as zinc-tolerant bacteria, the lowest inhibition of DPPH was observed in media amended with zinc than other metal. DPPH is a free radical generating compound and has been widely used to evaluate the free radical scavenging ability of various antioxidative compounds (Heo et al., 2006). Also, they mention that the reduction capability of DPPH radical was determined by the decrease induced by antioxidative compounds. The effect of antioxidant on DPPH radical scavenging was thought to be due to their hydrogen donating ability (Ilhami et al. 2004). Many reports have recently described the ability to scavenge DPPH free radical on some microorganisms (Athukorala et al., 2003). 
Table 3. Enzymatic and non-enzymatic antioxidant activities of Al. faecalis MG257493.1 filtrate under different heavy metals concentrations.

\begin{tabular}{|c|c|c|c|c|c|c|}
\hline \multirow{2}{*}{$\begin{array}{l}\text { Heavy } \\
\text { metals }\end{array}$} & \multirow{2}{*}{$\begin{array}{l}\text { Conc. } \\
\text { (mg/l) }\end{array}$} & \multicolumn{2}{|c|}{$\begin{array}{c}\text { Non-enzymatic } \\
\text { as }(\%) \text { DPPH after } 30 \text { min. }\end{array}$} & \multicolumn{3}{|c|}{ Enzymatic (absorbance per min.) } \\
\hline & & Residual & Inhibited & CAT & POD & PPO \\
\hline \multicolumn{2}{|c|}{$\begin{array}{c}\text { Without any heavy } \\
\text { metals }\end{array}$} & 56.3 & 43.7 & $\because \cdot \varepsilon 0$ & $\because \vee \vee \wedge$ & $\because 7 \varepsilon$ \\
\hline \multirow{2}{*}{$\mathbf{Z n}^{2+}$} & 1000 & 26.8 & 73.2 & $\because \cdot \leqslant 1$ &.$\cdot 74$ &. $.1 \mathrm{VV}$ \\
\hline & 1500 & 17.1 & 82.9 & 0.071 & 0.028 & 0.121 \\
\hline \multirow{2}{*}{$\mathrm{Cu}^{2+}$} & 1000 & 20.9 & 79.1 & .971 & $\because \cdot \mathrm{VV}$ &. YYr \\
\hline & 1500 & 7.70 & 92.3 & $\because .00$ & $\because \cdot \varepsilon \cdot$ &. $.1 \mathrm{~V}$ \\
\hline \multirow{2}{*}{$\mathbf{P b}^{2+}$} & 1000 & 10.1 & 89.9 & 0.047 & 0.039 & 0.203 \\
\hline & 1500 & 9.90 & 90.1 & 0.046 & 0.036 & 0.063 \\
\hline \multirow{2}{*}{$\mathrm{Cd}^{2+}$} & 1000 & 24.0 & 76.0 & $\cdot \cdot V r$ & 0.556 & $\because Y q \wedge$ \\
\hline & 1500 & 9.80 & 90.2 & $\because \leqslant \leqslant 9$ & 0.522 & .110 \\
\hline \multirow{2}{*}{$\begin{array}{c}\text { Heavy } \\
\text { metals } \\
\text { mixture }\end{array}$} & 1000 & 40.7 & 59.3 & $\because .0$ & .119 &.$M I r$ \\
\hline & 1500 & 26.9 & 73.1 & $\because \cdot 71$ & .974 & $\cdot r \cdot \Lambda$ \\
\hline
\end{tabular}

Respecting the enzymatic antioxidant activities of Al. faecalis MG257493.1, data in Table (3) showed that CAT activity was increased with the increasing of $\mathrm{Zn}^{2+}$ concentration in Al. faecalis MG257493.1 filtrate. The same trend was observed in filtrate contained mixture of heavy metals. Reverse results were observed in filtrate amended with $\mathrm{Cu}^{2+}, \mathrm{Pb}^{2+}$, $\mathrm{Cd}^{2+}$. Whereas, POD and PPO activities were higher in filtrate amended with each heavy metal at 1000 $\mathrm{mg} / \mathrm{l}$. Also, the activities of POD and PPO were increased and decreased with increasing of concentration of heavy metals mixture, respectively.

\section{Conclusion}

Out of the 71-zinc tolerant bacterial isolates from heavy metals contaminated sites in Egypt, UR45 isolate was found to show highest MIC and MTC for zinc at 4500 and $4000 \mathrm{mg} / \mathrm{l}$, respectively. This isolate was identified as Alcaligenes faecalis MG257493.1 by partial sequence of $16 \mathrm{~S}$ rRNA genes and showed metal tolerance to cadmium, lead and copper This study revealed the biosorption potential of the identified strain for different heavy metals under different $\mathrm{pH}$ values. Also, the antioxidant activities for metal tolerance by this strain represents a point of interest for possible environmental applications to remove the toxic effect of heavy metals from the contaminated environments.

\section{References}

Aboushanab, R.; Angle, J. and Chaney, R. 2006. Bacterial inoculants affecting nickel uptake by Alyssummurale from low, moderate and high $\mathrm{Ni}$ soils. Soil Biol. Biochem. 38, 2882-2889.
Aebi, H. 1984. B. Isolation, purification, characterization, and assay of antioxygenic enzymes: 13: Catalase in vitro. Methods Enzymol., Pp:121-126.

Ahemad, M. and Malik A. 2012. Bioaccumulation of heavy metals by zinc resistant bacteria isolated from agricultural soils irrigated with wastewater. J. Bacter., 2:12-21.

Ansari, M.I. and A. Malik, A. 2007. Biosorption of Nickel and Cadmium by metal resistant bacterial isolates from agricultural soil irrigated with industrial wastewater. Bio-Res. Tech., 98:31493153.

Ansari, R.A.; Qureshi A.A. and Ramteke D.S. 2016. Isolation and characterization of heavymetal resistant microbes from Industrial soil. Intr. J. Environ. Sci., 6(5): 670-680.

Athukorala, Y.; Lee, K.W.; Shahidi, F.; Heu, M.S.; Kim, H.T.; Lee, J.S. and Jeon, Y.J. 2003. Antioxidant efficacy of extracts of an edible red alga (Grateloupia filicina) in linoleic acid and fish oil. J. Food Lipids 10:313-327.

Augusto da Costa, A. C. and Duta, F. P. 2001. Bioaccumulation of copper, zinc, cadmium and lead by Bacillus sp., Bacillus cereus, Bacillus sphaericus and Bacillus subtilis. Braz. J. Microbiol., 32:1-5.

Banerjee, S.; Gothalwal, R.; Sahu, P.K. and Sao, S. 2015. Microbial Observation in Bioaccumulation of Heavy Metals from the Ash Dyke of Thermal Power Plants of Chhattisgarh, India. Adv. Biosci. Biotech., 6:131-138.

Bautista-Hernández, D.A.; Ramírez-Burgos, L.I.; Duran-Páramo, E.; Fernández-Linares, L. 2012. Zinc and Lead biosorption by Delftia tsuruhatensis: A bacterial strain resistant to metals isolated from mine tailings. J. Water Res. Protec., 4:207-216.

Burau, R. E. 1982. 'Lead', in A. L. Page et al. (eds), Methods of Soil Analysis, Part 2, Chemical and 
Microbiological Properties, 2nd ed., Agron. Monogr., ASA and SSSA, Madison, WI, U.S.A., 9:347-366.

Chen, L.; Luo, S. L.; Li, X. J.; Wan, Y.; Chen, J. L. and Liu, C. B. 2014. Interaction of $\mathrm{Cd}$ hyperaccumulator Solanum nigrum L. and functional endophyte Pseudomonas sp. Lk9onsoilheavymetalsuptake. Soil Biol. Biochem. 68, 300-308.

Chung, Y.C.; Chien, C.T.; Teng, K.Y. and Chou, S.T. 2006. Antioxidative and mutagenic properties of Zanthoxylum ailanthoides Sieb \& zucc. Food Chem. 97:418-425.

Congeevaram, S.; Dhanarani S.; Park J.; Dexilin, M.; Thamaraiselvi, K. 2007. Biosorption of chromium and nickel by heavy metal resistant fungal and bacterial isolates. J. Hazardous Materials, 146:270-277.

Ezzouhri, L.; Castro, E.; Moya, M.; Espinola, F. and Lairini, K. 2009. Heavy metal tolerance of filamentous fungi isolated from polluted sites in Tangier, Morocco. Afr. J. Microbiol. Res., 3(2):035-048.

Fang, Q.; Fan, Z.; Xie, Y.; Wang, X.; Li, K. and Liu, Y. 2016. Screening and Evaluation of the Bioremediation Potential of $\mathrm{Cu} / \mathrm{Zn}$-Resistant, Autochthonous Acinetobacter sp. FQ-44 from Sonchus oleraceus L., Front. Plant Sci., 7:1-12.

Farhadian, M.; Vachelard, C.; Duchez, D. et al. 2008. In situ bioremediation of monoaromatic pollutants in groundwater: A review. Biores. Technol., 99:5296-5308.

Filali, B.K.; Taoufik, J.; Zeroual, Y. et al. 2006. Waste water bacteria resistant to heavy metals and antibiotics. Curr. Microbiol., 41:151-156.

Gavrilesca, M. 2004. Removal of heavy metals from the environment by biosorption. Eng. Life Sci., 4(3):219-232.

Haferburg, G.; Reinicke, M.; Merten, D.; Buchel G. and Kothe E. 2007. Microbes adapted to acidic mine drainage as source for strain active in retention of aluminum or uranium. J. Geochemical Exploration, 92:196-204

Hassen, A.; Saidi, N.; Cherif, M. and Boudabous, A. 1998. Resistance of environmental bacteria to heavy metals. Bioreso. Technol., 64:7-15.

Heo, S.; Cha, S.; Lee, K. and Jeon, Y. 2006. Antioxidant Activities of Red Algae from Jeju Island. Algae. 21(1):149-156.

Heo, S.; Park, E.; Lee, K. and Jeon, Y. 2005. Antioxidant activities of enzymatic extracts from brown seaweeds. Bioresource Technol., 96:16131623.

Ilhami, G.; Sat, I.G.; Beydemir, S.; Elmastas, M. and Kufrevioglu, O.I. 2004. Comparison of antioxidant activity of clove (Eugenia caryophylata Thunb) buds and lavender (Lavandula stoechas L.). Food Chem., 87:393400 .
Issazadeh, K.; Jahanpour, N.; Pourghorbanali, F.; Raeisi, G. and Faekhondeh, J. 2013. Heavy metal resistance by bacterial strains. Ann. Biol. Res., 4:60-63.

Jackson, V.A; Paulse A.N.; Odendaal J.P.; Khan, S. and Khan, W. 2012. Identification of metaltolerant organisms isolated from the Plankenburg River, Western Cape, South Africa. Water S.A., 38:29-38.

Liu, H.; Chen, B.; Lan, Y.; Cheng, Y. 2004. Biosorption of $\mathrm{Zn}$ (II) and $\mathrm{Cu}$ (II) by the indigenous Thiobacillus thiooxidans. Chem. Eng. J., 97:195201.

Malik, A. and Jaiswal, R. 2000. Metal resistance in Pseudomonas strains isolated from soil treated with industrial wastewater. World J. Microbiol. Biotechnol., 16:177-182.

Malik A. 2004. Metal bioremediation through growing cells. Environ. Int., 30:261-278.

Mgbemena, C.I.; Nnokwe, J.C.; Adjeroh, L.A. and Onyemekara, N.N. 2012. Resistance of bacteria isolated from Otamiri River to heavy metals and some selected antibiotics. Curr. Res. J. Biol. Sci., 4:551-556.

Moghannem, S.A.; Refaat, B.M.; El-Sherbiny, G.M.; El-Sayed, M.H.; Elsehemy, I.A. and Kalaba, M.H. 2015. Characterization of heavy metal and antibiotic resistant bacteria isolated from polluted localities in Egypt. Egypt Pharmaceut. J., 14(3):158-165.

Narde, G.K.; Kapley, A. and Purohit, H.J. 2004. Isolation and Characterization of Citrobacter Strain HPC255 for Broad-Range Substrate Specificity for Chlorophenols

Oktay, K.; Schenken, R.S. and Nelson, J.F. 1995. Proliferating cell nuclear antigen marks the initiation of follicular growth in the rat. Biol. Reprod., 53, 295-301.

Onsa, G.H.; Saari, N.B.; Selamat, J. and Bakar, J. 2004. Purification and characterization of membranebound peroxidases from Metroxylon sagu. Food Chem., 85:365-376.

Owolabi, J.B. and Hekeu, M.M. 2015. Isolation and characterization of zinc resistant bacteria from a coil coating industrial wastewater treatment plant. Int. J. Environ. Sci., 5(5):1030-1042.

Purohit, P.K.; Kondev, J. and Phillips, R. 2003. Mechanics of DNA packaging in viruses. Proc. Nat. Acad. Sci. USA 100(6):3173-3178.

Sen, M. and Joshi, H. 2016. Determination of minimum inhibitory concentration and antibiotic susceptibility of zinc tolerant bacteria isolated from mine soil of zawar mines. Ind. J. Fund. Appl. Life Sci., 6(2):23-29.

Shetty, R. and Rajkumar, Sh. 2009. Biosorption of $\mathrm{Cu}$ (II) by metal resistant Pseudomonas check for this species in other resources sp. Int. J. Environ. Res., 3(1): 121-128.

Stevenson, K.; McVey, A.F.; Clark, I.B.; Swain, P.S. and Pilizota, T. 2016. General calibration of 
microbial growth in microplate readers. Sci. Reports, 6:1-7.

Tamura, K.; Dudley, J.; Nei, M. and Kumar, S. 2007. MEGA4: Molecular Evolutionary Genetics Analysis (MEGA) software version 4.0. Mol. Biol. Evol., 24(8):1596-1599.

Vadkertiova, R. and Slavikova, E. 2006. Metal tolerance of yeasts isolated from water, soil and plant environments. J. Basic Microbiol., 46:145152.
Vijayaraghavan, K. and Yun, Y.S. 2008. Bacterial biosorbents and biosorption. J. Biotech. Adv., 26: 266-291.

Xu, Y.; Ruan, J.; Hou, M.; Zhao, X.; Zheng, L.; Zhou, S. and Yuan, B. 2014. Stress of five heavy metals on the resistance of isolates from swine wastewater to four antibiotics. Hydrology Cur. Res., 5:1-5.

\section{عزل وتوصيف البكتريا المتحمله للزتك من الرواسب والتربه الملوثه فى مصر}

فى هذا البحث نم عزل ال عزله من البكتربا المتحمله للزنك من الرواسب والتربة الملوثه بالعناصر الثقبلة وذلك من ثناث عينات من

رواسب مصرف الرهاوى بمحافظة الجيزة (أعلى المصب - منتصف المصب - أسفل المصب) وكذلك تربة زراعية من منطقتى الجبل الأصفر وكفر علوان بمحافظة القليوبية. فى هذه الدراسه تم انتخاب أفضل عزلة وذللك بتقدير أقل تركيز مثبط وأعلى تركيز لتحمل البكتريا للزنك من خلال تركيزات

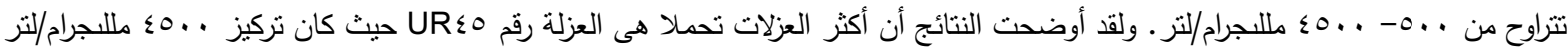

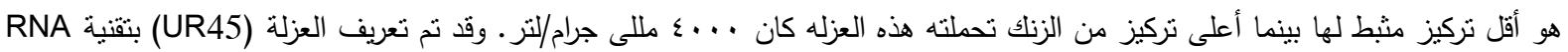

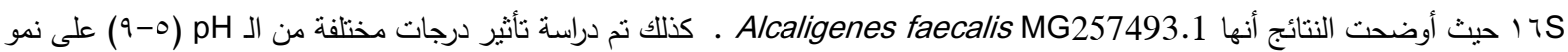
السلالة Alcaligenes faecalis MG257493.1 وذلك بهدف تحديد درجة pH المنلى والدنيا لمدى قدرتها على الامتصاص الحيوى للعناصر الثقيلة من خلال تقديرامنصاص المعدن والمعدن المنبقى عند تركيز ... . مللى جرام /لتز لكل من الرصاص والنحاس والكادميوم والزنك، وقد أوضحت النتائج أن8 هH هو الأمثل للنمو في البيئة المضاف لها عنصر الزنك والنحاس في حين اختلفت قيمة الامتصاص الحيوى وفقا للمعادن التى تم تقديرها. أيضا تم تقدير نشاط مضادات الأكسده الانزيمية للسلالة Alcaligenes faecalis MG257493.1 مثل (إنزيم الكتاليز

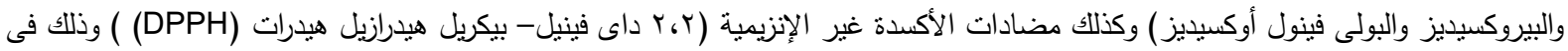
وجود نركيزات مختلفة من العناصر الثقيلة ... 1-. .01 ولقد أوضحت النتائج نشاط مضادات الأكسدة الانزيمية غير الإنزيمية يزاد بزيادة تركيز المعادن النقيلة قبد الدراسة. 